\title{
HLA-H and Associated Proteins in Patients with Hemochromatosis
}

\author{
Ernest Beutler, Carol West, and Terri Gelbart \\ Department of Molecular and Experimental Medicine, \\ The Scripps Research Institute, La Jolla, California, U.S.A.
}

\begin{abstract}
Background: The $845 \mathrm{~A}(\mathrm{C} 282 \mathrm{Y})$ mutation in the $H L A-H$ gene accounts for most cases of hereditary hemochromatosis in patients who are of European origin. Some lack this mutation, however, and it is not present in Asian patients. Thus, other mutations either in HLA-H or associated proteins may be present in such patients. HLA-H associates with $\beta-2$-microglobulin. Calreticulin associates with class 1 HLA proteins and appears to be identical with mobilferrin, a putative iron transport protein. These two proteins are therefore candidates for mutations in patients with hemochromatosis.

Materials and Methods: We have sequenced the coding region and parts of introns of the $H L A-H$ gene, the $\beta$-2-microglobulin gene, and the calreticulin (mobil-
\end{abstract}

ferrin) gene of 10,7 , and 5 hemochromatosis patients, respectively, selecting those who were not homozygous for the $845 \mathrm{~A}(\mathrm{C} 282 \mathrm{Y})$ mutation. The number of chromosomes at risk studied were 18 for HLA-H, 14 for $\beta$-2microglobulin, and 10 for calreticulin.

Results: We detected 3 new intronic polymorphisms in the $H L A-H$ gene, each a point mutation. Some differences from published sequences of $\beta$-2-microglobulin and calreticulin were documented, but these were uniformly present in all samples.

Conclusions: The lack of additional mutations in the $H L A-H$ gene is remarkable, and we speculate that the $\mathrm{C} 282 \mathrm{Y}$ mutation may be a gain-of-function change.

\section{INTRODUCTION}

Hereditary hemochromatosis is a disorder of iron metabolism characterized by the accumulation of large amounts of iron in the parenchymal cells of the liver, cirrhosis, diabetes, heart disease, and arthropathies. The genetic linkage of this disease to HLA-A and HLA-B has been recognized for over 20 years (1). However, it was only in 1996 that the HLA-H gene was identified and the mutations that give rise to HLA-linked hemochromatosis were found (2).

Most patients with hereditary hemochromatosis are homozygous for the $845 \mathrm{G} \rightarrow \mathrm{A}(845 \mathrm{~A}$; $\mathrm{C} 282 \mathrm{Y}$ ) mutation of the $H L A-H$ gene. In addition, some patients are compound heterozygotes for this mutation and a $187 \mathrm{C} \rightarrow \mathrm{G}(187 \mathrm{G}$; H63D) mutation of the $H L A-H$ gene. In most studies, however, $10 \%$ to $15 \%$ of Caucasian patients have

Address correspondence and reprint requests to: Ernest Beutler, Department of Molecular and Experimental Medicine, The Scripps Research Institute, 10550 North Torrey Pines Road, La Jolla, CA 92037, U.S.A. Tel: 619-784-8040; Fax: 619-784-2083; e-mail: beutler@scripps.edu. neither of these genotypes (2-5). Among Asian patients with hemochromatosis none have been found to have the C282Y mutation (3).

The cause of hemochromatosis in patients without the $\mathrm{C} 282 \mathrm{Y} / \mathrm{C} 282 \mathrm{Y}$ or $\mathrm{C} 282 \mathrm{Y} / \mathrm{H} 63 \mathrm{D}$ genotypes is unclear. It is possible that they have other mutations in HLA-H, although Feder et al., in their original report (2), found none. The cysteine $\rightarrow$ tyrosine substitution at amino acid 282 is believed to impair $\beta_{2}$-microglobulin binding of $\mathrm{HLA}-\mathrm{H}$, and it has been found that $\beta_{2}$-microglobulin-deficient mice accumulate iron. Indeed, it has been suggested that they represent an animal model of human hemochromatosis $(6,7)$. Another protein, calreticulin, is also of interest. This protein not only binds to HLA class 1 molecules (8) but is thought to be identical to mobilferrin, an iron transport protein (9).

Accordingly, we have examined the DNA sequences of HLA- $\mathrm{H}, \beta_{2}$-microglobulin, and calreticulin in a group of hemochromatosis patients, most of whom lacked the typical hemochromatosis genotype. 
TABLE 1. Primers and Conditions for Sequencing HLA-H, B2-microglobulin, and Calreticulin

\begin{tabular}{|c|c|c|c|c|}
\hline Gene & & PCR primers & $\begin{array}{c}\text { Annealing } \\
\text { temperature }\end{array}$ & Sequencing primers \\
\hline \multirow[t]{16}{*}{ HLA-H } & Exon 1 & 5'-CATTGCGAAGCTACTTTCCC-3' & $56^{\circ} \mathrm{C}$ & PCR primers \\
\hline & & 5'-AGTTTCGATTTTTCCACCCC-3' & & \\
\hline & Exon $2 \mathrm{a}$ & $5^{\prime}$-acatggttaaggcctgttgc- $3^{\prime}$ & $55^{\circ} \mathrm{C}$ & PCR primers \\
\hline & & 5'-GCCACATCTGGCTTGAAATT-3' & & \\
\hline & Exon $2 b$ & 5'-CATGAGAGTCGCCGTGTG-3' & $55^{\circ} \mathrm{C}$ & PCR primers \\
\hline & & $5^{\prime}$-cagctgtttccttcaagatgc- $3^{\prime}$ & & \\
\hline & Exon $3 a$ & $5^{\prime}$-tttggttgcagttaacaaggc- $3^{\prime}$ & $55^{\circ} \mathrm{C}$ & PCR primers \\
\hline & & 5'-GAATCTTGTGCCTTTCCCAC-3' & & \\
\hline & Exon $3 b$ & 5'-GGATTGGAGAGCAGCAGAAC-3' & $56^{\circ} \mathrm{C}$ & PCR primers \\
\hline & & $5^{\prime}$-aaactccaaccagggattcc- $3^{\prime}$ & & \\
\hline & Exon 4 & $5^{\prime}$-tggcaagggtaaacagatcc- $3^{\prime}$ & $58^{\circ} \mathrm{C}$ & PCR primers \\
\hline & & $5^{\prime}$-ctcaggcactcctctcaacc- $3^{\prime}$ & & \\
\hline & Exon 5 & $5^{\prime}$-gcctgaggaggtatatggc- $3^{\prime}$ & $58^{\circ} \mathrm{C}$ & PCR primers \\
\hline & & $5^{\prime}$-gagacttccccttgttcct-3' & & \\
\hline & Exon 6 & $5^{\prime}$-tgggtgaatgaggaaaataagg- $3^{\prime}$ & $55^{\circ} \mathrm{C}$ & PCR primers \\
\hline & & $5^{\prime}$-ctagggatcaccggcatg-3' & & \\
\hline \multirow[t]{6}{*}{$\beta 2$-microglobulin } & Promoter-exon 1 & $5^{\prime}$-tcctgattggctgggcacgc- $3^{\prime}$ & $63^{\circ} \mathrm{C}$ & PCR primers \\
\hline & & $5^{\prime}$-cagagcgggagggtaggaga- $3^{\prime}$ & & \\
\hline & Exon 2 & $5^{\prime}$-accctggcaatattaatgtgtc- $3^{\prime}$ & $59^{\circ} \mathrm{C}$ & PCR primers \\
\hline & & $5^{\prime}$-tacacaactttcagcagcttac- $3^{\prime}$ & & \\
\hline & Exon 3 & $5^{\prime}$-ttttagacatttgttagtacatgg-3' & $58^{\circ} \mathrm{C}$ & PCR primers \\
\hline & & $5^{\prime}$-ctgtaggattcttctttccctg- $3^{\prime}$ & & \\
\hline \multirow[t]{4}{*}{ Calreticulin cDNA } & Exons $1-3$ & 5'-CCGTCCGTCACTGCAGAGC-3' & $60^{\circ} \mathrm{C}$ & 5'-CAGAGCCGCTGCCGGAGGGT-3' \\
\hline & & 5'-ACAGCTTCACATAGCCGCC-3' & & 5'-CCCACAGTCGATGTTCTGCT-3' \\
\hline & Exons 3-5 & 5'-CACGCTTTTATGCTCTGTCG-3' & $58^{\circ} \mathrm{C}$ & 5'-TGTCGGCCAGTTTCGAGCCT-3' \\
\hline & & 5'-AGTCCTCAGGCTTGGAGTC-3' & & 5'-GTGGGATCATCGATCTTGGC-3' \\
\hline
\end{tabular}



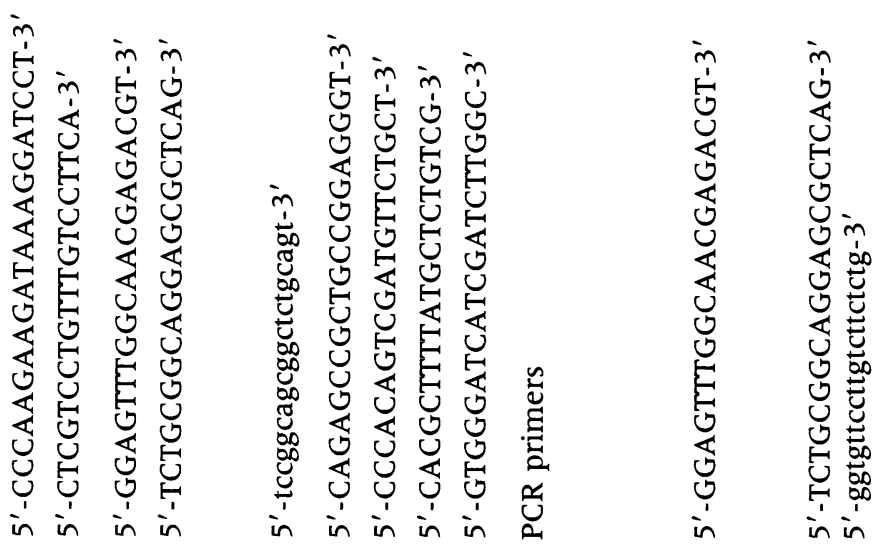

$\begin{array}{llllll}0 & 0 & 0 & 0 & 0 & u \\ 0 & 0 & 0 & 0 & 0 & 0 \\ \text { in } & \text { in } & 0 & 0 & \text { in } & \text { in }\end{array}$
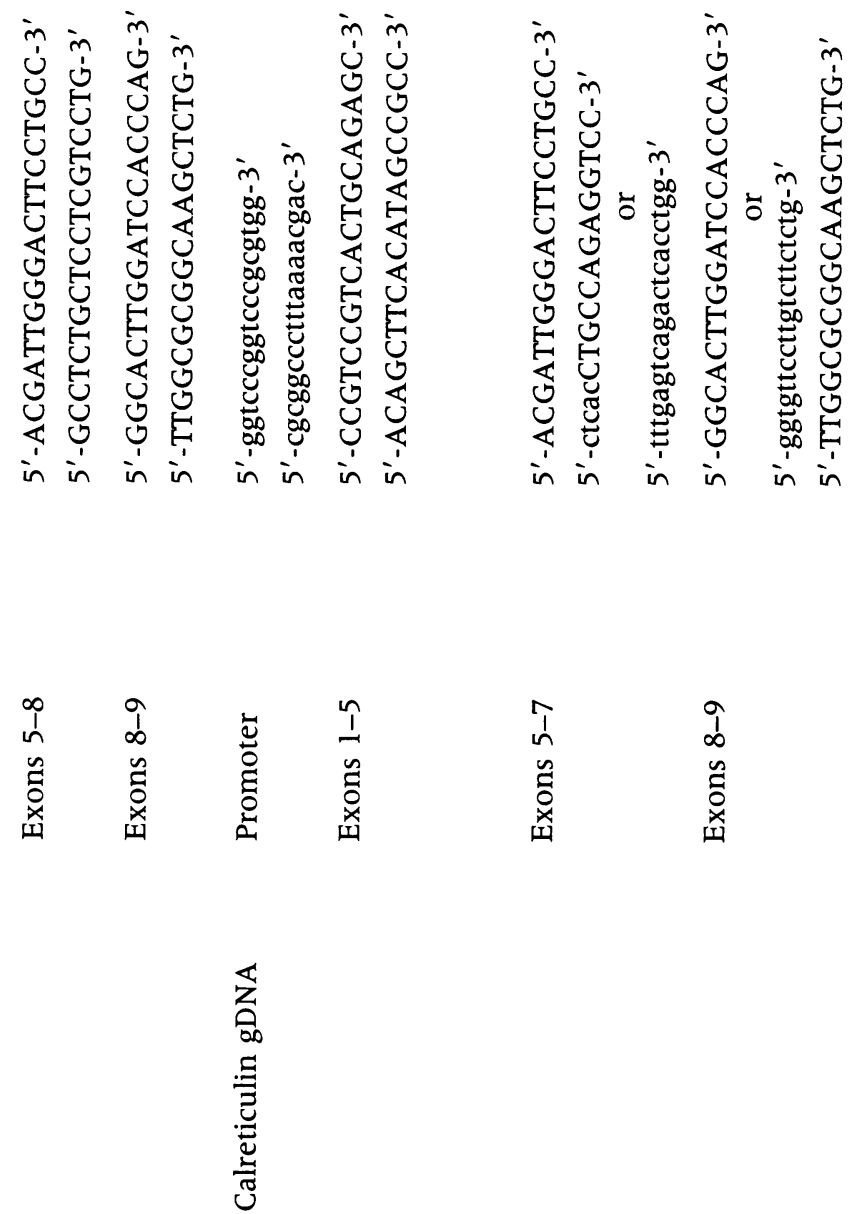

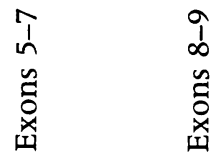

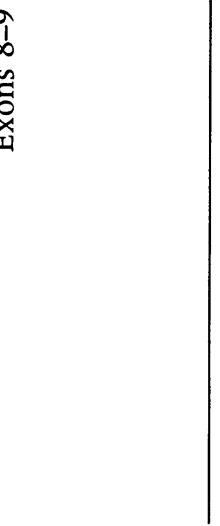


IVS $2(+4) t / c$

Exon 2-AACCACAGCAAGGgta ${ }_{c}^{t}$ gtggagagggggcctcaccttcctgaggttgtcagagcttt

IVS 4 (-44) t/c gggtgggc ${ }_{c}^{t}$ gagggtggcaatcaaaggctttaacttgcttttctgttttagAGCCCTCACCGT-Exon 5

IVS 5 (-47) g/a caagatg $\mathrm{g}_{\mathrm{a}}$ tgcctaggttgtgatgcctcttcctgggtctcttgtctccacagGAGGAGCCAT-Exon 6

FIG. 1. HLA-H intron polymorphisms

\section{MATERIALS AND METHODS}

\section{Patients}

Fourteen patients of European extraction and 4 patients of Asian extraction who had been diagnosed with hemochromatosis and who were not homozygous for the HLA-H C282Y mutation are included in this study. Clinical diagnoses of hemochromatosis were based on either serum iron and ferritin levels, liver biopsies, response to phlebotomy, or a combination of these. Whenever possible, information was obtained about a family history of hemochromatosis, but such a history was obtained unequivocally for only 1 patient from whom all genes were sequenced.

\section{Polymerase Chain Reaction (PCR) Amplification and Sequencing}

Genomic DNA was extracted from peripheral blood leukocytes using conventional methods. Total RNA was isolated from peripheral blood leukocytes with Trizol (GIBCO/BRL, Gaithersburg, MD).

The exons of HLA-H were amplified from genomic DNA using polymerase chain reaction (PCR) with primers based on the sequence of Ruddy et al. (10) as deposited in GenBank as U91328 (Table 1). $\beta-2$ microglobulin exons and promoter were amplified from genomic DNA by PCR using primers based on sequences M17986 and M17987 in GenBank (Table 1). When mRNA was available, calreticulin was amplified by PCR from first-strand CDNA made using an RT-PCR kit (Stratagene, La Jolla, CA). Promoter and cDNA sequences were obtained from GenBank (V59053, S78537, M84739) and appropriate primers for amplification of the coding region and promoter were designed (Table 1). In some cases, calreticulin was amplified from genomic DNA with cDNA primers and with intronic primers from sequence data obtained using cDNA primers (Table 1).

When PCR was performed on genomic DNA, the amplification system contained $33.5 \mathrm{mM}$ Tris- $\mathrm{HCl}, \mathrm{pH} 8.3,8.3 \mathrm{mM}\left(\mathrm{NH}_{4}\right)_{2} \mathrm{SO}_{4}, 85 \mu \mathrm{g} / \mathrm{ml}$ BSA, $3.35 \mathrm{mM} \mathrm{MgCl}_{2}, 5 \%$ DMSO, $0.2 \mathrm{mM}$ dNTPs, $250 \mathrm{ng}$ of each oligonucleotide primer, and $0.5-1 \mu \mathrm{g}$ of genomic DNA in $100 \mu \mathrm{l}$. After denaturation at $98^{\circ} \mathrm{C}$ for $5 \mathrm{~min}$, DNA was amplified for 30 cycles at $94^{\circ} \mathrm{C}$ for $30 \mathrm{sec}, 54-60^{\circ} \mathrm{C}$ for $30 \mathrm{sec}$, and $72^{\circ} \mathrm{C}$ for $30-90 \mathrm{sec}$.

PCR products were purified on QIAquick PCR purification columns (Qiagen, Chatsworth, CA) and sequenced using either nested or PCR primers on an automated sequencer (ABI, Foster City, CA).

\section{RESULTS}

\section{HLA-H}

The entire coding region of the $H L A-H$ gene of 10 patients was sequenced. Included were 8 patients with the normal $845 \mathrm{G} / 845 \mathrm{G}$ genotype and 2 patients who were heterozygous for the $845 \mathrm{~A}$ (C282Y) mutation, both of whom were compound heterozygotes for 187G (H63D). All of the coding region except for a portion of exon 3 was sequenced in an additional patient with the normal $845 \mathrm{G} / 845 \mathrm{G}$ genotype.

No additional mutations were found in the coding region of HLA-H. However, three polymorphic sites were detected in introns 2,4 , and 5. The relevant sequences are shown in Fig. 1. In studying a large number of normal subjects and patients with hemochromatosis, 6 of the 8 possible haplotypes created by these diallelic sites have been identified (data not shown).

\section{及-2-Microglobulin}

The entire coding region of the $\beta-2$-microglobulin gene of 7 hemochromatosis patients was sequenced. Included were 6 patients with the normal $845 \mathrm{G} / 845 \mathrm{G}$ genotype and 1 patient who was a compound heterozygote for the 845A (C282Y) and 187G (H63D) mutations. There were some 
differences between the sequences that we obtained and those recorded in GenBank under accession numbers M17986 and M17987. In the GenBank M17986 sequence, nucleotides 837838 in the signal peptide are given as gg and $\mathrm{nt}$ 942 was given as a c. Only a single $\mathrm{g}$ was present at nt 837 and there was a t at nt 942 in all of our samples. In exon 2 of sequence M17987, nt 200 is given as an a; we found a $\mathrm{c}$ in all samples. However, GenBank sequence J00105 agrees with the sequence that we observed. In the $3^{\prime}$ untranslated region, nt 1134 is given as a single g. We found two g's at this location.

Apart from these differences, which were found in all samples, the $\beta-2$ microglobulin sequence was identical to the sequences deposited in GenBank. Accordingly, it appears that there were no mutations that could account for iron storage disease in these samples.

\section{Calreticulin (mobilferrin)}

The entire coding region and the promoter of the calreticulin gene of 5 patients was sequenced. Included were 3 patients with the normal $845 \mathrm{G} /$ $845 \mathrm{G}$ genotype and 2 patients who were heterozygous for the 845A (C282Y) mutation, one of whom was a compound heterozygote for $187 \mathrm{G}$ (H63D). There were three differences in the sequences we obtained from the reference sequence GenBank X59053. We found that nt 165-169 were cccgc instead of gggcg, that a t at nt 201 was deleted and that two g's were found at nt 368 rather than the one given in the GenBank file. However, two other GenBank sequences, X85727 and AD000092, agreed with the sequence that we found. Moreover, we sequenced the promoter region from an additional 8 hemochromatosis patients with the $845 \mathrm{G} /$ $845 \mathrm{G}$ genotype and from 3 normal subjects, finding the same sequence. Therefore, it as apparent that no mutations that could account for hemochromatosis were found in any of the samples examined.

\section{DISCUSSION}

The discovery of the $H L A-H$ gene on chromosome 6 is a major advance in the understanding of hemochromatosis. The $\mathrm{C} 282 \mathrm{Y}$ mutation accounts for over $80 \%$ of patients with hereditary hemochromatosis with European ancestry. However, more than $10 \%$ of European patients with hemochromatosis and most Asian patients with this disease do not have this mutation. It would be a reasonable expectation that some or all of these patients would have other mutations of this gene. In other autosomal recessive diseases in which one or more predominant mutations representing a founder effect are present, many other less common mutations producing the same disease have been detected (11-14). However, Feder et al. (2) found only the C282Y and H63D mutations to be associated with hereditary hemochromatosis; they were unable to find any other mutations in the 30 patients that they studied who were not homozygous for the $\mathrm{C} 282 \mathrm{Y}$. These were our finding, too, in the 10 patients with 18 chromosomes at risk that we studied. We are surprised at this finding, but with total lack of information regarding the mechanism by which the homozygous C282Y substitution causes increased iron absorption and of how the heterozygote for this mutation is complemented by the H63D substitution, one can only speculate about the lack of other mutations in HLA-H in hemochromatosis patients. Possibly, the $\mathrm{C} 282 \mathrm{Y}$ mutation produces a gain-of-function rather than a loss-of-function. If this were the case, other mutations that prevented synthesis of HLA-H might not complement this mutation or cause a similar phenotype. The sickle cell mutation can be regarded as an example of such a gain-of-function mutation. Of the hundreds of mutations known to exist in the hemoglobin $\beta$-chain gene, it is only the glu $\rightarrow$ val substitution in codon 6 that supports sickling. The putative, partially dominant nature of the $\mathrm{C} 282 \mathrm{Y}$ mutation $(15,16)$ fits a gain-of-function model, but data concerning the phenotype of "heterozygotes" will need to be re-evaluated to separate compound heterozygotes for the H63D mutation from simple heterozygotes.

Since HLA class 1 molecules associate with other proteins during transport to the membrane, it seemed possible that mutations of such molecules might create phenocopies of the HLA-H mutations. The most attractive candidates for such mutations are $\beta$-2-microglobulin and calreticulin. $\beta$-2-microglobulin seems to be an outstanding candidate because it is believed to associate with HLA-H (2) and because targeted disruption of the murine gene is associated with iron storage (6). Calreticulin is known to associate with many proteins, including HLA class I molecules (8), but our particular interest in this molecule is based on the demonstration that the iron transport protein mobilferrin seems to be identical with calreticulin (9). A number of dif- 
ferences were found in the sequences of these genes from those deposited in GenBank. However, these were found in the homozygous form in all samples examined. Only a few of the differences were in coding regions, and in these we found other GenBank sequences that were identical to ours. Thus, we concluded that there were no significant mutations in either of these genes in any of the hemochromatosis patients studied.

In sequencing the $H L A-H$ gene we found three new polymorphic sites. All of these are intronic and are unlikely by their nature and location to cause abnormalities in splicing. We have detected 6 haplotypes of HLA-H. If the $845 \mathrm{~A}$ and $187 \mathrm{G}$ hemochromatosis mutations are included, 8 haplotypes of the HLA-H gene can now be differentiated. Because these are diallelic markers, they may prove to be useful in genetic studies of this portion of chromosome 6 .

\section{ACKNOWLEDGMENTS}

This study is manuscript 10764-MEM from The Scripps Research Institute and was supported by National Institutes of Health grants HL25552 and RR00833, and the Stein Endowment Fund. We are grateful to D. A. Ruddy and colleagues at Mercator Genetics Corp. for making available intron sequences of HLA-H prior to publication.

\section{REFERENCES}

1. Simon M, Pawlotsky Y, Bourel M, Fauchet R, Genetet B. (1975) Hémochromatose idiopathique: Maladie associée à l'antigène tissulaire. Nouv. Presse Med. 4: 1432.

2. Feder JN, Gnirke A, Thomas W, et al. (1996) A novel MHC class I-like gene is mutated in patients with hereditary haemachromatosis. Nature Genet. 13: 399-408.

3. Beutler E, Gelbart T, West C, et al. (1996) Mutation analysis in hereditary hemochromatosis. Blood Cells Mol. Dis. 22: 187-194.

4. Calandro L, Thorsen T, Barcellos L, Griggs J, Baer D, Sensabaugh GF. (1996) Mutation analysis in hereditary hemochromatosisCommentary. Blood Cells Mol. Dis. 22: 194A194B.

5. Jouanolle AM, Gandon G, Jezequel P, et al.
(1996) Haemochromatosis and HLA-H. Nature Genet. 14: 251-252.

6. Santos M, Schilham MW, Rademakers LHPM, Marx JJM, de Sousa M, Clevers H. (1996) Defective iron homeostasis in beta2microglobulin knockout mice recapitulates hereditary hemochromatosis in man. J. Exp. Med. 184: 1975-1985.

7. Rothenberg BE, Voland JR. (1996) $\beta_{2}$ Knockout mice develop parenchymal iron overload: A putative role for class I genes of the major histocompatibility complex in iron metabolism. Proc. Natl. Acad. Sci. U.S.A. 93: 1529-1534.

8. Sadasivan B, Lehner PJ, Ortmann B, Spies T, Cresswell P. (1996) Roles for calreticulin and a novel glycoprotein, tapasin, in the interaction of MHC class I molecules with TAP. Immunity 5: 103-114.

9. Conrad ME, Umbreit JN, Moore EG. (1993) Rat duodenal iron-binding protein mobilferrin is a homologue of calreticulin. Gastroenterology 104: 1700-1704.

10. Ruddy DA, Kronmal GS, Lee VK, et al. (1997) A 1.1-Mb transcript map of the hereditary hemochromatosis locus. Genome Res. In press.

11. Sferra TJ, Collins FS. (1993) The molecular biology of cystic fibrosis. Annu. Rev. Med. 44: 133-144.

12. Shore S, Tomczak J, Grebner EE, Myerowitz R. (1992) An unusual genotype in an Ashkenazi Jewish patient with Tay-Sachs disease. Hum. Mutat. 1: 486-490.

13. Mahuran DJ. (1995) Beta-hexosaminidase: Biosynthesis and processing of the normal enzyme, and identification of mutations causing Jewish Tay-Sachs disease. Clin. Biochem. 28: 101-106.

14. Beutler E, Gelbart T. (1997) Hematologically important mutations: Gaucher disease. Blood Cells Mol. Dis. 23: 2-7.

15. Bulaj ZJ, Griffen LM, Jorde LB, Edwards CQ, Kushner JP. (1996) Clinical and biochemical abnormalities in people heterozygous for hemochromatosis. N. Engl. J. Med. 335: 1799-1805.

16. Powell LW, Jazwinska EC. (1996) Hemochromatosis in heterozygotes. N. Engl. J. Med. 335: 1837-1839.

Communicated by E. Beutler. Accepted April 21, 1997. 